\title{
Макєঠovıкá
}

Tóp. 4, Ap. 1 (1960)

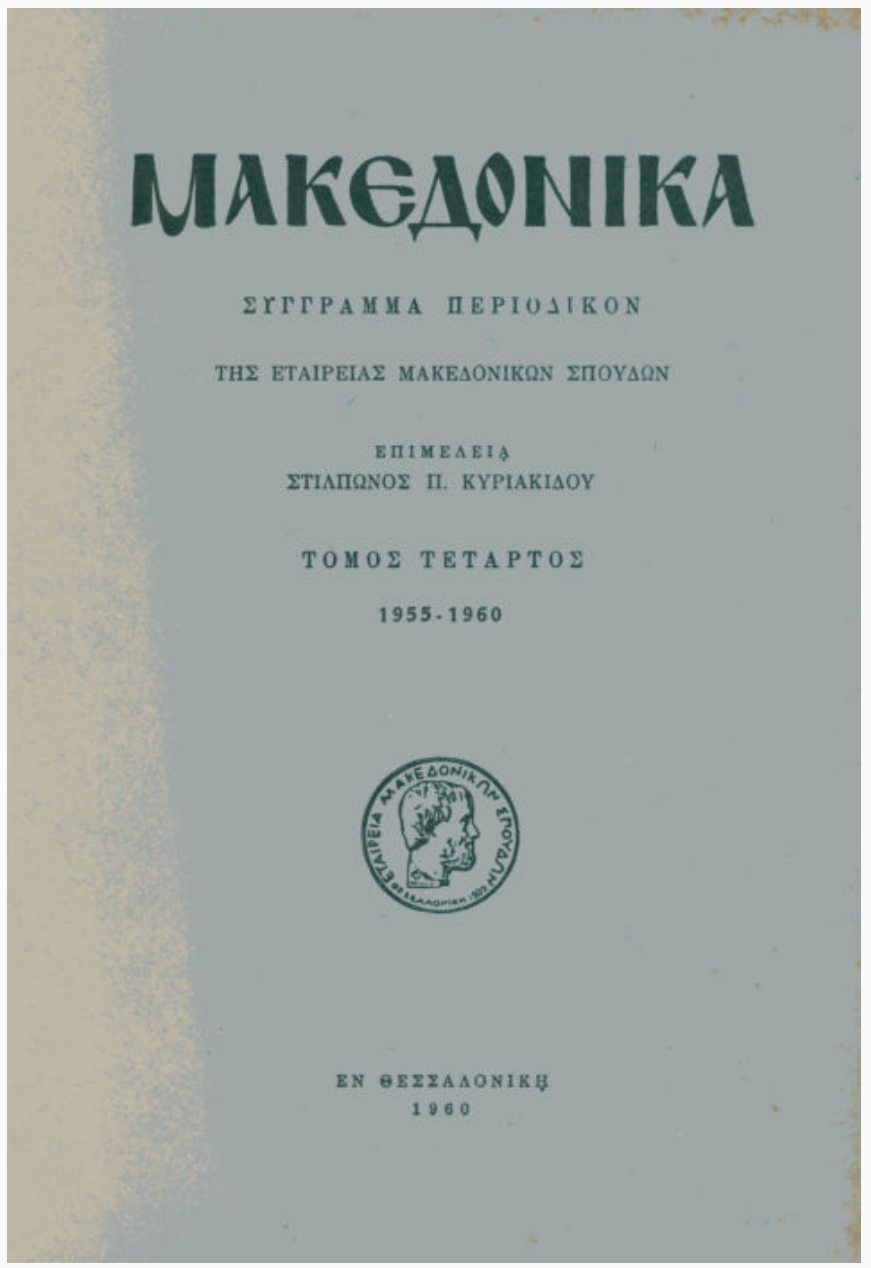

\section{Albania, Stavro Skendi editor}

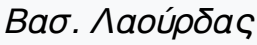

doi: $10.12681 /$ makedonika.748

Copyright @ 2015, Baб. ^aoúpঠac

\section{(@) $\odot \Theta(\odot)$}

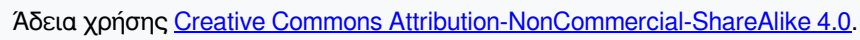

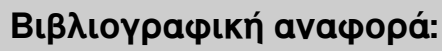

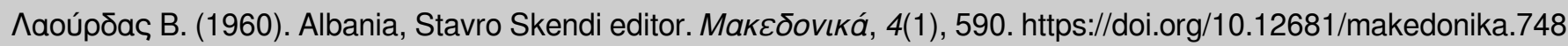




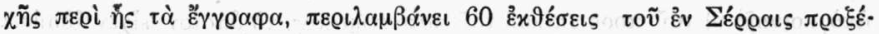

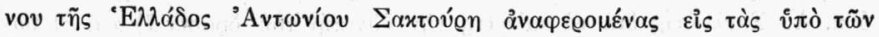

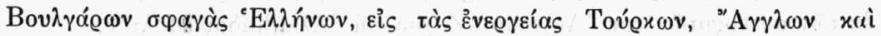

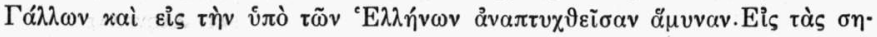

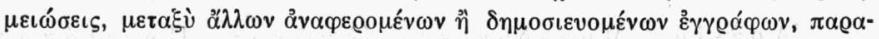

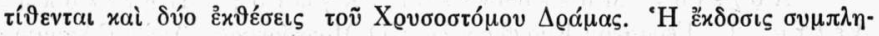

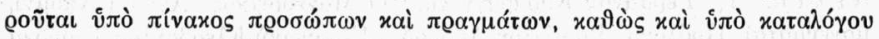

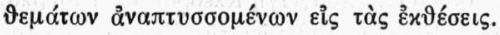

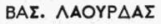

A 1 b a n i a, Stavro Skendi editor. Mid - European Studies Center of the Free Europe Committee, Inc. New York 1957, $\sigma \varepsilon \lambda .389$.

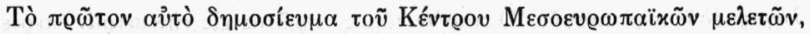

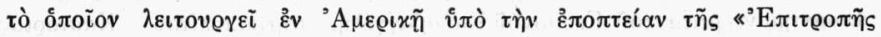

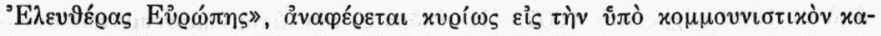

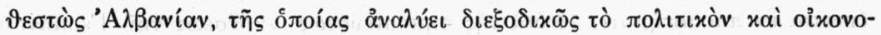

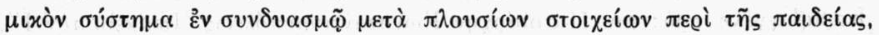

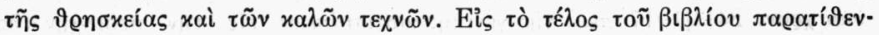

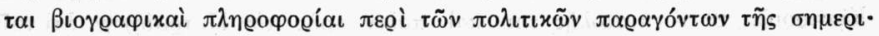

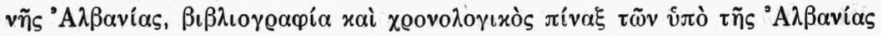

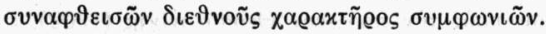

BAE. NAOYP $\triangle A \Sigma$

$\mathrm{Yug}$ os lavia, with an introduction by $\mathrm{R}$ ober $\mathrm{t} F$. B y rnes. Mid-European Studies Center of the Free Europe Committee,

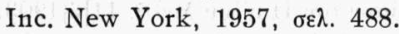

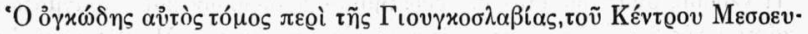

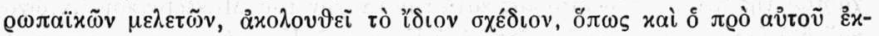

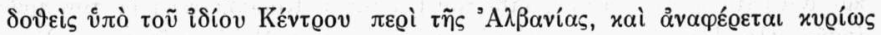

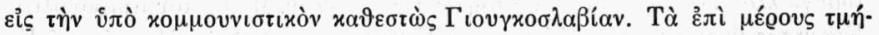

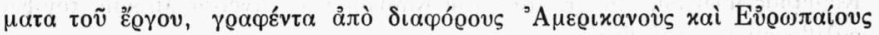

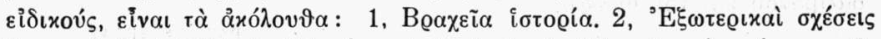

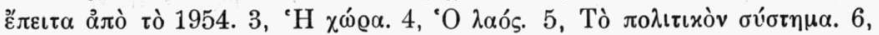

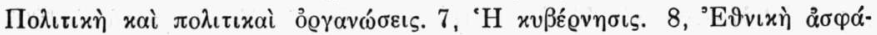

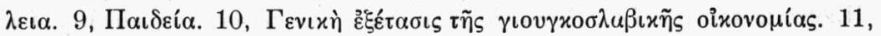

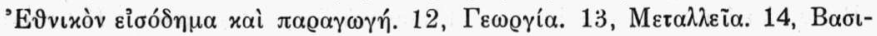

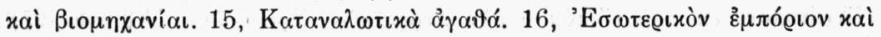

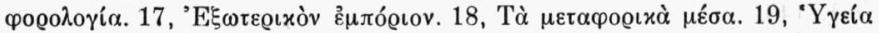

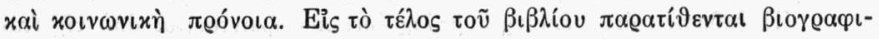

